\title{
Antimicrobial resistance of Staphylococcus spp. from small ruminant mastitis in Brazil ${ }^{1}$
}

\author{
Chirles A. França ${ }^{2}$, Rodolfo M. Peixoto ${ }^{3}$, Marielly B. Cavalcante ${ }^{2}$, Natoniel F. Melo ${ }^{4}$, \\ Celso José B. Oliveira ${ }^{5}$, JosirLaine A. Veschi ${ }^{4}$, Rinaldo A. Mota ${ }^{6}$ and Mateus M. Costa ${ }^{2 *}$
}

\begin{abstract}
França C.A., Peixoto R.M., Cavalcante M.B., Melo N.F., Oliveira C.J.B., Veschi J.L.A., Mota R.A. \& Costa M.M. 2012. Antimicrobial resistance of Staphylococcus spp. from small ruminant mastitis in Brazil. Pesquisa Veterinária Brasileira 32(8):747-753. Projeto de Irrigação Senador Nilo Coelho s/n, Universidade Federal do Vale do São Francisco, Campus Ciências Agrárias, Rodovia BR 407 Km 12, Lote 543, Petrolina, PE 56300-990, Brazil. E-mail: mateus.costa@univasf.edu.br

The study aimed to determine the antimicrobial resistance patterns and to identify molecular resistance markers in Staphylococcus spp. $(\mathrm{n}=210)$ isolated from small ruminant mastitis in Brazil. The antimicrobial resistance patterns were evaluated by the disk diffusion test and by detection of the presence of mecA, blaZ, ermA, ermB, ermC and $m s r A$ genes by PCR. The efflux pump test was performed using ethidium bromide and biofilm production was determined by Congo red agar test along with PCR for detection of the icaD gene. The isolates were most resistant to amoxicillin (50.0\%), streptomycin $(42.8 \%)$, tetracycline $(40.4 \%)$, lincomycin $(39.0 \%)$ and erythromycin $(33.8 \%)$. Pan-susceptibility to all tested drugs was observed in 71 (33.8\%) isolates and 41 Staphylococcus isolates were positive for the efflux pump. Although phenotypic resistance to oxacillin was observed in $12.8 \%$ of the isolates, none harbored the mecA gene. However, $45.7 \%$ of the isolates harbored blaZ indicating that beta-lactamase production was the main mechanism associated with staphylococci resistance to beta-lactams in the present study. The other determinants of resistance to antimicrobial agents ermA, ermB, ermC, and msrA were observed in $1.4 \%, 10.4 \%, 16.2 \%$, and $0.9 \%$ of the isolates, respectively. In addition, the icaD gen was detected in $32.9 \%$ of the isolates. Seventy three isolates (54 from goats and 19 from sheep) were negative for all resistance genes tested and 69 isolates presented two or more resistance genes. Association among blaZ, ermA, ermB, erm $\mathrm{C}$ and efflux pump were observed in 17 isolates, 14 of which originated from goats and three from sheep. The data obtained in this study show the resistance of the isolates to beta-lactamics, which may be associated with the use of antimicrobial drugs without veterinary control.
\end{abstract}

INDEX TERMS: Biofilm, efflux pump, goats, milk, sheep.

\footnotetext{
${ }^{1}$ Received on November 21, 2011.

Accepted for publication on April 3, 2012.

${ }^{2}$ Projeto de Irrigação Senador Nilo Coelho, Universidade Federal do Vale do São Francisco, Campus Ciências Agrárias, BR 407 Km 12, Lote 543, Petrolina, PE 56300-990. *Autor para correspondência: mateus.costa@univasf.edu.br

${ }^{3}$ Instituto Federal de Educação, Ciência e Tecnologia do Sertão Pernambucano, Campus Floresta, Rua Projetada s/n, Caetano II, Floresta, PE 56400-000, Brazil.

${ }^{4}$ Embrapa Semi-Árido (CPATSA), BR $428 \mathrm{Km} \mathrm{152,} \mathrm{Zona} \mathrm{Rural,} \mathrm{Cx.} \mathrm{Postal}$ 23, Petrolina, PE 56302-970, Brasil.

${ }^{5}$ Centro de Ciências Agrárias, Universidade Federal da Paraíba, Rod. PB $079 \mathrm{Km} \mathrm{12}$, Zona Rural, Areia, PB 58397-000, Brazil.

${ }^{6}$ Área de Medicina Veterinária Preventiva, Universidade Federal Rural de Pernambuco (UFRPE), Av. Dom Manuel de Medeiros s/n, Dois Irmãos, Recife, PE 52171-900, Brazil.
}

RESUMO.- [Resistência antimicrobiana de Staphylococcus spp. de mastite de pequenos ruminantes no Brasil.] O presente trabalho teve como objetivo determinar os padrões de resistência a agentes antimicrobianos e identificar marcadores moleculares de resistência em Staphylococcus spp. $(\mathrm{n}=210)$ isolados de mastite de pequenos ruminantes no Brasil. Os padrões de resistência a agentes antimicrobianos foram avaliados pelo teste de difusão em disco e pela detecção da presença dos genes mecA, blaZ, ermA, ermB, ermC e msrA via PCR. 0 teste da bomba de efluxo foi realizado utilizando brometo de etídio e a produção de biofime foi determinada pelo teste do vermelho congo em paralelo com o PCR para detecção do gene icaD. 
Os isolados foram mais resistentes a amoxicilina $(50,0 \%)$, estreptomicina $(42,8 \%)$, tetraciclina $(40,4 \%)$, lincomicina $(39,0 \%)$ e eritromicina $(33,8 \%)$. Setenta e um $(33,8 \%)$ isolados foram sensíveis a todas as drogas testadas e 41 foram positivos para a bomba de efluxo. Embora a resistência fenotípica a oxacilina tenha sido observada observada em $12,8 \%$ dos isolados, nenhum possuiu o gene mecA. Entretanto, 45,7\% dos isolados continham a gene blaZ, indicando que a produção de beta-lactamases foi o principal mecanismo associado com a resistência dos Staphylococcus aos beta-lactâmicos. Os outros determinantes de resistência a agentes antimicrobianos ermA, ermb, ermC e $m s r A$ foram observados em $1,4 \%, 10,4 \%, 16,2 \%$ e $0,9 \%$ dos isolados respectivamente. Além disso, o gene icaD foi detectado em $32,9 \%$ dos isolados. Setenta e três isolados (54 de cabras e 19 de ovelhas) foram negativos para todos os genes de resistência testados e 69 isolados apresentaram dois ou mais genes de resistência. A associação entre blaZ, ermA, ermB, ermC e bomba de efluxo foi observada em 17 isolados dos quais 14 eram oriundos de cabras e três de ovelhas. Os dados obtidos no presente estudo indicam a resistência dos isolados aos beta-lactâmicos, o que pode estar associado ao uso sem controle veterinário destas drogas nos animais.

TERMOS DE INDEXAÇÃO: Biofilme, bomba de efluxo, cabra, leite, ovelha.

\section{INTRODUCTION}

Mastitis is a serious concern to both meat and milk producers since the infection can lead to considerable economic losses due to reduction in milk yield, decreased milk quality and treatment costs (Sawant et al. 2009). Staphylococci are considered to be the most important mastitis causing agents in ruminants (Aires-de-Sousa et al. 2007, Taponen \& Pyörälä 2009) and antimicrobial therapy is usually required in treatment (Bergonier et al. 2000, Contreras et al. 2007, Pÿorälä \& Taponen 2009). However, there is evidence that resistance to antibiotics is increasing in staphylococci infected food animals (Phillips et al. 2004). The emergence of multidrug resistance (MDR) in Staphylococcus spp. is a problem for concern in animal production and issues related to public health (Kumar et al. 2009, Sawant et al. 2009, Virdis et al. 2010).

More than $90 \%$ of the Brazilian goat and sheep population is concentrated in the Northeast region, which makes it the leading goat milk supplier in the country. However, the production system is predominantly extensive or semi-intensive and mostly comprised of small scale producers with major technical limitations. Although staphylococci species have been identified as the most common mastitis-causing agent in small ruminant species in Brazil (Silva et al. 2004), knowledge about antimicrobial resistance mechanisms in those bacteria is still lacking.

Therefore, the aim of this study was to determine the antimicrobial resistance patterns and to characterize the antimicrobial resistance mechanisms of Staphylococcus species isolated from subclinical mastitis in goats and sheep in Northeastern Brazil.

\section{MATERIALS AND METHODS}

\section{Staphylococci isolates}

The investigation included Staphylococci $(n=210)$ from subclinical mastitis cases in goats $(n=171)$ and sheep $(n=39)$ raised in 25 herds (17 goat herds, 6 sheep herds and 2 mixed herds) from the states of Pernambuco and Bahia in Northeastern Brazil. The isolated Staphylococcus spp. were identified by morphological and biochemical tests according to Quinn et al. (1994).

The bacteria were deposited in the bacteria bank of the Animal Microbiology and Immunology Laboratory of the Universidade Federal do Vale do São Francisco (Federal University of São Francisco Valley) (Univasf) and at the Bacteriosis Laboratory of the School of Veterinary Medicine, Universidade Federal Rural de Pernambuco (Federal Rural University of Pernambuco) (UFR$\mathrm{PE}$ ) and included 37 S. epidermidis (17.6\%), 35 S. intermedius (16.6\%), 35 S. hyicus (16.6\%), 34 S. aureus (16.2\%), 23 S. caprae (11.0\%), five S. gallinarum (2.3\%), three S. simulans $(1.4 \%)$ and one $S$. saprophyticus $(0.5 \%)$. Thirty seven isolates $(17.6 \%)$ were identified as coagulase negative Staphylococcus (CNS) since the species could not be identified.

\section{Antimicrobial susceptibility test}

Antimicrobial resistance patterns were determined by the Kirby-Bauer disk diffusion test performed according to recommendations (CLSI 2006). The drugs tested and their concentrations were: gentamycin $(10 \mu \mathrm{g})$, streptomycin $(10 \mu \mathrm{g})$, enrofloxacin $(05 \mu \mathrm{g})$, norfloxacin $(10 \mu \mathrm{g})$, ciprofloxacin $(05 \mu \mathrm{g})$, amoxicillin $(10 \mu \mathrm{g})$, oxacillin $(01 \mu \mathrm{g})$, doxycycline $(30 \mu \mathrm{g})$, tetracycline $(30 \mu \mathrm{g})$, erythromycin $(15 \mu \mathrm{g})$, lincomycin $(02 \mu \mathrm{g})$ and rifampicin $(05 \mu \mathrm{g})$. As a control for antimicrobial testing, we used the reference strains Staphylococcus aureus ATCC 25923 and Escherichia coli ATCC 49247. The multidrug resistance rate (MDR rate) was calculated by dividing the number of antimicrobial resistant groups (Krumperman et al. 1983).

\section{Efflux pump mechanism detection}

Efflux pump screening in Staphylococcus spp. was carried out as previously described in Bjorland et al. (2005). Thus, isolates were grown on Mueller Hinton Agar $(\mathrm{MH})$ containing ethidium bromide $(0.5 \mathrm{mg} / \mathrm{ml})$ for 24 hours at $37^{\circ} \mathrm{C}$. Isolates were considered positive for efflux mediated resistance when no fluorescence under UV examination was observed.

\section{Screening for biofilm production}

Biofilm production was assessed by inoculating isolates onto Congo Red Agar, according to Greco et al. (2008). After incubation at $37^{\circ} \mathrm{C}$ for $24 \mathrm{~h}$, black colonies were considered as biofilm producers.

\section{Polymerase chain reaction (PCR)}

Antimicrobial resistance genes (mecA, blaZ, ermA, B, C and $m s r A$ ) and the biofilm producing gene icaD were identified by PCR using the primers and cycle conditions described by Greco et al. (2008), Murakami et al. (1991) and Sawant et al. (2009) (Table 1). Shortly, bacterial genomic DNA was obtained by thermal extraction (Greco et al. 2008). DNA template $(2 \mu \mathrm{l})$ was added to a $23 \mu \mathrm{l}$ master mix containing $4 \mathrm{pmol}$ of each primer, $0.4 \mathrm{mM}$ of dNTPs mix, 1U of Taq DNA polymerase (Ludwig- Biotec), buffer $(10 \mathrm{mM}$ Tris- $\mathrm{HCl}$ [ph 8.5] and $50 \mathrm{mM} \mathrm{KCl}$ ) and $2 \mathrm{mM} \mathrm{MgCl}_{2}$. PCR products were electrophoresed in $1.5 \%$ agarose gel stained with ethidium bromide $(0.5 \mu \mathrm{g} / \mathrm{mL})$ and observed under UV illumination. DNA from reference isolates harboring the target genes were used as positive controls. 
Table 1. Oligonucleotide primers, amplification conditions (temperature/ denaturation time/annealing/ extension) and amplicon sizes for the polymerase chain reactions

\begin{tabular}{|c|c|c|c|c|c|}
\hline Genes & Primers & Oligonucleotide sequences & Amplification conditions & Amplicon size (pb) & Reference \\
\hline \multirow[t]{2}{*}{$i c a \mathrm{D}$} & SeicaDFw & AAGCCCAGACAGAGGCAATATCCA & $\begin{array}{c}30 \mathrm{~s}-94^{\circ} \mathrm{C} \\
30 \mathrm{~s}-53.5^{\circ} \mathrm{C}\end{array}$ & 249 & Greco et al. 2008 \\
\hline & SeicaDRev & AGTACAAACAAACTCATCCATCCGA & $30 \mathrm{~s}-72^{\circ} \mathrm{C}$ & & \\
\hline \multirow[t]{2}{*}{ mecA } & SA-1 & CGGTAACATTGATCGCAACGTTCA & $\begin{array}{c}30 \mathrm{~s}-94^{\circ} \mathrm{C} \\
68^{\circ} \mathrm{C}-15 \text { cycles }\end{array}$ & 214 & Murakami et al. 1991 \\
\hline & SA-2 & CTTTGGAACGATGCCTAATCTCAT & $\begin{array}{c}60^{\circ} \mathrm{C}-20 \text { cycles } \\
30 \mathrm{~s}-72^{\circ} \mathrm{C}\end{array}$ & & \\
\hline \multirow[t]{2}{*}{ blaZ } & blaZ F & AAGAGATTTGCCTATGCTTC & $\begin{array}{l}30 \mathrm{~s}-94^{\circ} \mathrm{C} \\
30 \mathrm{~s}-50^{\circ} \mathrm{C}\end{array}$ & 517 & Sawant et al. 2009 \\
\hline & blaZ R & GCTTGACCACTTTTATCAGC & $30 \mathrm{~s}-72^{\circ} \mathrm{C}$ & & \\
\hline \multirow[t]{2}{*}{ ermA } & ermA F & ATCGGATCAGGAAAAGGACA & $\begin{array}{c}1 \mathrm{~min}-94^{\circ} \mathrm{C} \\
30 \mathrm{~s}-49^{\circ} \mathrm{C}\end{array}$ & 486 & Sawant et al. 2009 \\
\hline & ermA R & CACGATATTCACGTTTTACCC & $30 \mathrm{~s}-72^{\circ} \mathrm{C}$ & & \\
\hline \multirow[t]{2}{*}{ erm $\mathrm{B}$} & ermB F & AAGGGCATTTAACGACGAAA & $\begin{array}{l}1 \mathrm{~min}-94^{\circ} \mathrm{C} \\
30 \mathrm{~s}-49.5^{\circ} \mathrm{C}\end{array}$ & 423 & Sawant et al., 2009 \\
\hline & ermB R & CTGTGGTATGGCGGGTAAGT & $30 \mathrm{~s}-72^{\circ} \mathrm{C}$ & & \\
\hline \multirow[t]{2}{*}{ ermC } & ermC F & TGAAATCGGCTCAGGAAAAG & $\begin{array}{c}1 \mathrm{~min}-94^{\circ} \mathrm{C} \\
30 \mathrm{~s}-52^{\circ} \mathrm{C}\end{array}$ & 272 & Sawant et al. 2009 \\
\hline & ermC R & CAAACCCGTATTCCACGATT & $30 \mathrm{~s}-72^{\circ} \mathrm{C}$ & & \\
\hline \multirow[t]{2}{*}{$m s r A$} & msrA F & TGGTACTGGCAAAACCACAT & $\begin{array}{l}30 \mathrm{~s}-94^{\circ} \mathrm{C} \\
30 \mathrm{~s}-52^{\circ} \mathrm{C}\end{array}$ & 1000 & Sawant et al. 2009 \\
\hline & $m s r A \mathrm{R}$ & AAACGTCACGCATGTCTTCA & $30 \mathrm{~s}-72^{\circ} \mathrm{C}$ & & \\
\hline
\end{tabular}

Table 2. Antimicrobial resistance rates (\%)of Staphylococcus spp. causing mastitis in goat and sheep in Brazil determined by the disk diffusion test

\begin{tabular}{|c|c|c|c|c|c|c|c|c|c|c|}
\hline \multicolumn{11}{|c|}{ Staphylococci species } \\
\hline Gen & $00 \%$ & $1(4$ & $3(8$ & $0(0.0$ & $3(8$. & $4(1$ & 0 & & $5(13.5 \%)$ & 16 \\
\hline Enrofloxacin $(5 \mu \mathrm{g})$ & $6(17.6 \%)$ & $1(4.3 \%)$ & $4(10.8 \%)$ & $0(0.0 \%)$ & $3(8.5 \%)$ & $2(5.7 \%)$ & $0(0$. & $0(0.0 \%)$ & $1(2.7 \%)$ & 17 \\
\hline $\operatorname{acin}(10 \mu \mathrm{g})$ & $10(29.4 \%)$ & $1(4.3 \%)$ & $6(16.2 \%)$ & $1(20 \%)$ & $7(20 \%)$ & $3(8.5 \%)$ & $\%)$ & $0(0.0 \%)$ & $0(0.0 \%)$ & 29 \\
\hline in $(30 \mu \mathrm{g})$ & $5(14.7 \%)$ & $3(13.0 \%)$ & $1(2.7 \%)$ & $2(40 \%)$ & $6(17.1 \%)$ & $0(0.0 \%)$ & $0(0.0 \%)$ & $0(0.0 \%)$ & $2(5.4 \%)$ & 19 \\
\hline Doxycycline $(30 \mu \mathrm{g})$ & $4(11.7 \%)$ & $3(13.0 \%)$ & $6(16.2 \%)$ & $0(0.0 \%)$ & $4(11.4 \%)$ & $4(11.4 \%)$ & $0(0.0 \%)$ & $0(0.0 \%)$ & $4(10.8 \%)$ & 25 \\
\hline Tetracycline $(30 \mu \mathrm{g})$ & $5(14.7 \%)$ & $11(47.8 \%)$ & $18(48.6 \%)$ & $0(0.0 \%)$ & $14(40.0 \%)$ & $18(51.4 \%)$ & $0(0.0 \%)$ & $0(0.0 \%)$ & $19(51.3 \%)$ & 85 \\
\hline Erythromycin $(10 \mu \mathrm{g})$ & $4(11.7 \%)$ & $10(43.4 \%)$ & $16(43.2 \%)$ & $0(0.0 \%)$ & $12(34.3 \%)$ & $9(25.7 \%)$ & $0(0.0 \%)$ & $0(0.0 \%)$ & $20(54.0 \%)$ & 71 \\
\hline Lincomycin $(2 \mu \mathrm{g})$ & $4(11.7 \%)$ & $11(47.8 \%)$ & $19(51.3 \%)$ & $1(20 . \%)$ & $11(31.4 \%)$ & $15(42.8 \%)$ & $0(0.0 \%)$ & $0(0.0 \%)$ & $21(56.7 \%)$ & 82 \\
\hline Rifampicin $(30 \mu \mathrm{g})$ & $13(38.2 \%)$ & $1(4.3 \%)$ & $5(13.5 \%)$ & $0(0.0 \%)$ & $6(17.1 \%)$ & $4(11.4 \%)$ & $1(100 \%)$ & $0(0.0 \%)$ & $5(13.5 \%)$ & 35 \\
\hline
\end{tabular}

\section{RESULTS}

The antimicrobial resistance patterns of the Staphylococcus spp. isolates are shown in Table 2. The isolates were most resistant to amoxicillin (50.0\%), followed by streptomycin $(43.4 \%)$, tetracycline $(40.5 \%)$, lincomycin (39.0\%) erythromycin (33.8\%), rifampicin (16.7\%), oxacillin $(16.7 \%)$, norfloxacin $(13.8 \%)$, doxycicline $(12.0 \%)$, ciprofloxacin $(8.5 \%)$, enrofloxacin $(8.1 \%)$ and gentamycin $(7.62 \%)$. Considering the resistance patterns of staphylococci according to the host species (Fig.1), higher resistances were observed in the goat isolates as compared to sheep isolates for the majority of the antimicrobials tested, such as amoxicillin ( $57.3 \%$ vs. $18.0 \%$ ), streptomycin ( $46.8 \%$ vs. $10.3 \%)$, tetracycline ( $45.6 \%$ vs. $10.3 \%)$, lincomycin ( $45.6 \%$ vs. $7.7 \%$ ) erythromycin (35.1\% vs. $23.1 \%)$, rifampicin ( $25.7 \%$ vs. $23.1 \%$ ), oxacillin ( $15.8 \%$ vs. $12.8 \%$ ), norfloxacin ( $10.5 \%$ vs. $5.1 \%)$, doxycicline $(10.5 \%$ vs $7.7 \%)$ and enrofloxacin $(2.9 \%$ vs. $0 \%)$. Lower resistance rates in goat isolates were only observed for ciprofloxacin (5.9\% vs. $10.3 \%)$ and

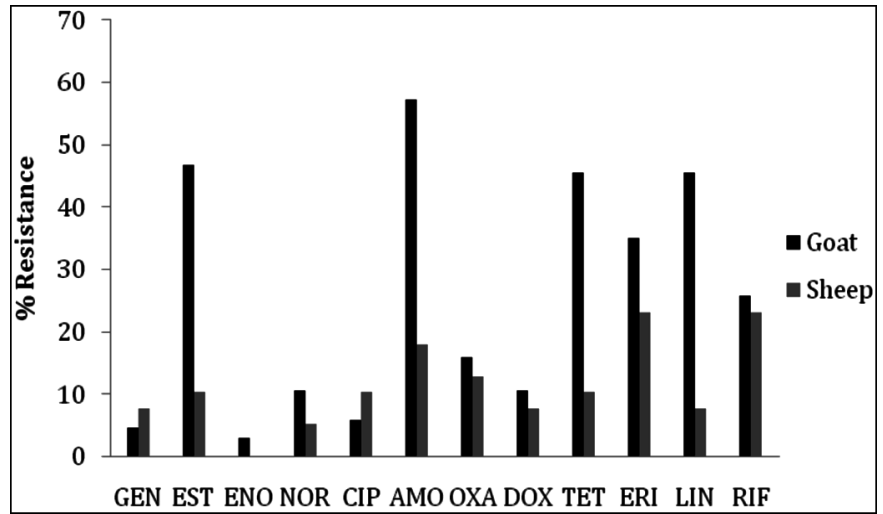

Fig.1. Frequencies of resistance of Staphylococcus spp. isolated from mastitis in goats and sheep according to the disk diffusion test. GEN: gentamycin, EST: estreptomycin, ENO: enrofloxacin, NOR: norfloxacin, CIP: ciprofloxacin, AMO: amoxicillin, OXA: oxacillin, DOX: doxycycline, TET: tetracycline, ERI: eritromycin, LIN: lincomycin and RIF: rifampicin. 
Table 3. Distribution of Staphylococcus spp. isolates from small ruminant mastitis in Brazil according to resistance genes and multidrug resistance rates (MDR)

\begin{tabular}{lccccccccc}
\hline \multirow{2}{*}{ Resistance gene pattern } & \multicolumn{7}{c}{ Multidrug resistance rate (MDR) } \\
\cline { 2 - 8 } & 0 & 0.14 & 0.29 & 0.43 & 0.57 & 0.71 & 0.86 & 1 \\
\hline blaZ & 1 & 6 & 4 & 5 & 9 & 4 & 7 & - \\
ermA & - & - & - & - & - & - & - & 1 \\
ermB & - & - & - & 1 & - & 1 & - & - \\
ermC & - & - & - & - & - & 3 & 3 & 1 \\
icaD & 4 & 6 & 8 & 2 & - & - & - & - \\
blaZ, icaD & 5 & 7 & 6 & 3 & 5 & 1 & 3 & - \\
blaZ, ermB & 1 & 1 & 2 & - & - & - & 1 & - \\
blaZ, ermC & - & - & - & 1 & - & 4 & 5 & - \\
blaZ, $m$ mrA & - & - & - & - & - & - & 1 & - \\
blaZ, ermA, icaD & - & - & - & - & - & - & 1 & - \\
blaZ, ermB, ermC & - & - & - & - & - & 4 & - & 2 \\
blaZ, ermB, icaD & - & 1 & 1 & - & 1 & 1 & - & - \\
blaZ, ermC, icaD & - & 1 & 1 & - & 1 & - & - & - \\
blaZ, ermA, ermB, icaD & - & - & - & - & - & - & - & 1 \\
ermB, ermC & - & - & - & - & - & 1 & - & - \\
icaD, $m s r \mathrm{~A}$ & 1 & - & - & - & - & - & - & - \\
icaD, ermC & - & - & 1 & - & - & 2 & 1 & - \\
icaD, ermB, ermC & - & 1 & 1 & 1 & - & - & - & - \\
No pattern & 4 & 15 & 18 & 14 & 8 & 7 & 4 & 3 \\
TOTAL & 16 & 38 & 42 & 27 & 24 & 28 & 26 & 8
\end{tabular}

gentamycin (4.7\% vs. $7.7 \%)$. No resistance to gentamycin was observed in Staphylococcus aureus isolates.

The MDR rate ranged from 0 to 1 (Table 3). Fifteen $(7.1 \%)$ isolates were susceptible to all tested antimicrobial drugs, ten of which (4.8\%) originated from mastitis in goats and five $(2.4 \%)$ in sheep. Multidrug resistance was more frequently observed in goat isolates $(44.7 \%)$ than in sheep isolates $(23.3 \%)$. Seven goat isolates $(3.4 \%)$ and one sheep isolate $(0.5 \%)$ were resistant to all tested drugs. A high number of isolates $(n=88)$ exhibiting simultaneous resistance to four or more groups of antimicrobial drugs were observed in this study. Eight $(3.81 \%)$ isolates were resistant to all tested drugs.

Of the 210 isolates tested, 41 (19.6\%) were considered positive for the efflux pump mechanism, 34 isolates originating from goat mastitis and seven isolates from sheep mastitis. Considering the host species, a similar rate for the efflux pump was observed between goat (18\%) and sheep $(23.3 \%)$ isolates. Considering the red Congo agar method for biofilm production, only 16 (7.6\%) isolates (15 isolates from goat and one from sheep) tested positive for biofilm.

Table 4 presents the frequencies of antimicrobial resistance markers in the Staphylococci isolates investigated. Seventy three isolates (54 from goats and 19 from sheep) were negative to all resistance genes tested and 69 isolates presented two or more resistance genes simultaneously. All isolates tested were negative for mecA, although the bla gene was detected in $96(45.8 \%)$ isolates. A higher occurrence of blaZ was observed among CNS, reaching $73 \%$ in $S$. epidermidis and $56.6 \%$ in S. caprae. On the other hand, the frequency of blaZ in S. aureus and S. intermedius was $20.6 \%$ and $25.7 \%$, respectively. Considering the host species, 78 (45.7\%) isolates from goats and 18 (46.1\%) from sheep harbored the blaZ gene.

In regard to other resistance markers, ermA, ermB and ermC markers were observed in three (1.4\%), 22 (10.5\%) and $34(16.2 \%)$ isolates, respectively. The three ermA positive isolates and all 34 staphylococci harboring the ermC gen originated from goat mastitis. Moreover, of the 22 isolates harboring ermB, only one (4.6\%) was isolated from sheep. Association among blaZ, ermA, ermB, erm $\mathrm{C}$ and the efflux pump were observed in 17 isolates, 14 originating from goats and three from sheep.

From the 41 staphylococci positive for the efflux pump mechanism, only two $(1.0 \%)$ harbored the $m s r$ A gene, according to the PCR results. The biofilm-encoding gene icaD was detected in $69(33.0 \%)$ isolates (Table 4$)$.

\section{DISCUSSION AND CONCLUSIONS}

A high rate of antimicrobial resistance to staphylococci isolated from goat and sheep mastitis in Northeastern Brazil was observed in the present study. This may be associated with the greater use of antimicrobial drugs in this species, because sheep in the region under evaluation have the double use of producing milk and meat and are carried in a more

Table 4. Distribution of resistance genes in 210 Staphylococcus spp. isolates from small ruminant mastitis in Brazil according to PCR results

\begin{tabular}{|c|c|c|c|c|c|c|c|c|c|c|c|c|c|c|c|c|}
\hline \multirow[t]{2}{*}{ Species } & \multirow[t]{2}{*}{ Total } & \multicolumn{7}{|c|}{ Goats } & \multirow[t]{2}{*}{ Total } & \multicolumn{7}{|c|}{ Sheep } \\
\hline & & $i c a \mathrm{D}$ & mecA & blaZ & ermA & ermB & ermC & $m s r A$ & & $i c a \mathrm{D}$ & mecA & blaZ & ermA & ermB & ermC & msrA \\
\hline S. aureus $(\mathrm{n}=34)$ & 13 & $5(38.5 \%)$ & - & $6(46.1 \%)$ & - & $2(15.4 \%)$ & - & - & 1 & - & - & $1(100 \%)$ & - & - & - & - \\
\hline S. caprae $(\mathrm{n}=23)$ & 27 & $10(37.0 \%)$ & - & $12(44.5 \%)$ & - & $1(3.7 \%)$ & $3(11.1 \%)$ & $1(3.7 \%)$ & 1 & - & - & $1(100 \%)$ & - & - & - & - \\
\hline $\begin{array}{l}\text { S. epidermidis } \\
\qquad(\mathrm{n}=37)\end{array}$ & 58 & $14(24.1 \%)$ & - & $24(41.4 \%)$ & - & $9(15.5 \%)$ & $11(19.0 \%)$ & - & 5 & $2(40 \%)$ & - & $3(60 \%)$ & - & - & - & - \\
\hline $\begin{array}{l}\text { S. gallinarium } \\
(\mathrm{n}=5)\end{array}$ & 10 & $3(30 \%)$ & - & $2(20 \%)$ & - & $3(30 \%)$ & $2(20 \%)$ & - & 0 & - & - & - & - & - & - & - \\
\hline S. hyicus $(\mathrm{n}=35)$ & 27 & $11(40.7 \%)$ & - & $11(40.7 \%)$ & - & $1(3.7 \%)$ & $4(14.9 \%)$ & - & 6 & $3(50 \%)$ & - & $3(50 \%)$ & - & - & - & - \\
\hline $\begin{array}{l}\text { S. intermedius } \\
(\mathrm{n}=35)\end{array}$ & 17 & $5(29.4 \%)$ & - & $4(23.5 \%)$ & $2(11.8 \%)$ & $2(11.8 \%)$ & $4(23.5 \%)$ & - & 12 & $6(50.0 \%)$ & - & $5(41.7 \%)$ & - & $1(8.3 \%)$ & - & - \\
\hline $\begin{array}{l}\text { S. saprophyticus } \\
\qquad(\mathrm{n}=1)\end{array}$ & 0 & - & - & - & - & - & - & - & 1 & - & - & $1(100 \%)$ & - & - & - & - \\
\hline $\begin{array}{l}\text { S. simulans } \\
(\mathrm{n}=3)\end{array}$ & 4 & $3(75 \%)$ & - & - & - & - & - & $1(25 \%)$ & 0 & - & - & - & - & - & - & - \\
\hline $\begin{array}{l}\text { Staphylococcus spp. } \\
(\mathrm{n}=37)\end{array}$ & 38 & $5(13.2 \%)$ & - & $19(50 \%)$ & $1(2.6 \%)$ & $3(7.9 \%)$ & $10(26.3 \%)$ & - & 6 & $2(33.3 \%)$ & - & $4(66.7 \%)$ & - & - & - & - \\
\hline TOTAL & 194 & 56 & - & 78 & 03 & 21 & 34 & 2 & 32 & 13 & 0 & 18 & 0 & 1 & 0 & 0 \\
\hline
\end{tabular}


extensive way. The same fact is reported by Aires-de-Sousa et al. (2007) comparing the sensitivity of Staphylococcus aureus isolates from bovine, goats and sheep.

One hundred fifty five (74\%) isolates were resistant to two or more antimicrobial drugs simultaneously and pan-susceptibility was observed in only fifteen Staphylococcus spp. isolates $(7.1 \%)$. Although the antimicrobial resistance observed in the present study seems to be higher than those previously reported in Brazil and elsewhere (Aires-de-Sousa et al. 2007, Kumar et al. 2009), direct comparisons must be performed carefully since most investigations focused only on Staphylococcus aureus. Except for enrofloxain and norfloxacin, the present results indicate lower resistance rates to streptomycin, tetracycline and amoxicillin in Staphylococcus aureus as compared to CNS (Table 2). However, the multidrug resistant rate indicated here is higher than that (8\%) recently reported in a study on antimicrobial resistance in coagulase positive and negative staphylococci from sub-clinical mastitis in goats (Virdis et al. 2010).

The frequency of resistance to beta-lactams varied considerably and ranged from $12 \%$ (doxycycline) to $50 \%$ (amoxicillin). This rate of resistance to amoxicillin was higher than that described in $S$. aureus from mastitis in Brazilian dairy goats (Aires-de-Sousa et al. 2007) but very similar to beta-lactam resistance rates reported worldwide for Staphylococcus aureus from cattle mastitis (Rabello et al. 2005, Sawant et al. 2009, Virdis et al. 2010).

There is no previous study regarding distribution of the blaZ gene in small ruminant species. In the present study, blaZ was detected in $45.8 \%$ of all Staphylococcus spp. isolates, which supports the high resistance level against beta-lactams observed in the disk diffusion test, particularly for the goat species. In Staphylococcus spp. isolates from sheep, the higher blaZ gene frequency is unrelated with the disk diffusion test (Fig.1). Discrepancies in genetic and phenotypic tests are reported in previous studies in dairy cattle (Sawant et al. 2009). The frequency of the blaZ gene in coagulase positive staphylococci $20.6 \%$ in $S$. aureus and $25.7 \%$ in $S$. intermedius) was lower than that observed in many CNS (73\% in S. epidermidis; $56 \%$ in $S$. caprae, and $62 \%$ in CNS). The frequency of blaZ described here was higher than the $18.4 \%$ reported by Sawant et al. (2009) but lower than the $100 \%$ observed in penicillin resistant $S$. aureus from Denmark (Vesterholm-Nielsen et al. 1999). The results indicate that beta-lactamase production encoded by blaz might be the main mechanism associated with resistance to beta-lactams in staphylococci causing mastitis in goats and sheep in Brazil, as previously reported in other countries for dairy cattle (Olsen et al. 2006, Taponen \& Pyörälä, 2009).

Resistance to methicillin was found in $16.7 \%$ of the Staphylococcus isolates, but none of them harbored the mecA gene. Although a recent study (Onni et al. 2010) reported multi-drug resistance mediated by the mecA gene in $S$. epidermidis isolated from dairy sheep herds, methicillin resistant Staphylococcus spp. are considered unusual in veterinary medicine (Guérin-Faublée et al. 2003). This type of resistance is associated with resistance to all beta-lactam drugs, despite the apparent susceptibility obtained in vitro tests (CLSI 2006, Sawant et al. 2009). In Brazil, a frequency of $5.6 \%$ of the mecA gene in CNS is of animal origin, but no detection of CNS in humans was reported (Soares et al. 2008). Transfer of beta-lactam resistance genes may occur among human and animal Staphylococcus spp. isolates and is a public health concern (Vesterholm-Nielsen et al. 1999, Katayama et al. 2005, Olsen et al. 2006). Caution should be exercised in regard to raw milk ingestion, which is a common practice in rural areas under development. However, further studies for the purpose of determining the real importance of MRSA from animal-derived foods on public health issues are required, since MRSA isolated from food animals do not necessarily correspond genetically to those clones linked to human infections (Kwon et al. 2005).

Of the 71 erythromycin resistant isolates, only 41 presented efflux pump in $\mathrm{MH}$ agar screening and two and 48 isolates were positive to msrA and erm genes by PCR respectively. The resistance to macrolides and tetracycline may occur due to several mechanisms in addition to efflux pump, such as modification enzymes and ribosome protection (Butaye et al. 2003, Gatermann et al. 2007, Hassan et al. 2007). The results showed high resistance rates against erythromycin in S. caprae (43\%), S. epidermidis (43\%), and in other non-identified CNS (56\%). This corroborates a previous report showing high resistance rates for erythromycin in S. epidermidis, and a high frequency of the mrsA gene in those species (Sawant et al. 2009). Possible differences in phenotypic and genotypic resistance to erythromycin may be explained by other unidentified macrolide resistance mechanisms which are common in CNS isolates (Fiebelkorn et al. 2003). These are ultimately related to geographic location and therapeutic drug usage (Pitkälä et al. 2004, Gatermann et al. 2007). The presence of two or more antimicrobial resistance genes may be associated with multidrug resistant Staphylococcus spp. (Sawant et al. 2009).

The high multidrug resistance rates observed in CNS as compared to CPS are in accordance with previous reports (Kumar et al. 2008, Sawant et al. 2009) and support the hypothesis that CNS might play an important role as a source of genes resistant to S. aureus (Taponen \& Pyörälä, 2009). Considering such an assumption, studies about host specificity in Staphylococcus aureus and other pathogenic agents could provide useful information about the epidemiological importance of CNS as reservoirs of genes resistant to pathogenic strains for humans. However, because CNS are the major mastitis causing agents in small ruminants, the high frequency of resistant genes in such species reported here is worth noting. Although goats and sheep are raised on pasture in extensive or semi-intensive production systems in Brazil, the widespread use of some antimicrobials for clinical treatment purposes might be associated with the high resistance rates (Ribeiro et al. 2009, Schmidt et al. 2009), as observed in the present study. Uncontrolled antimicrobial usage was reported by farmers and agricultural technicians in the sampling region. Indeed, high resistance levels against specific antimicrobials may be associated with their frequent and long-term use on the farm (Pitkälä et al. 2004, Kumar et al. 2009). 
The drugs showing the lowest resistance rates were gentamycin, enrofloxacin and ciprofloxacin, which are in accordance with other studies on mastitis in several ruminant species (Hussain et al. 2007, Kumar et al. 2009). Virdis et al. (2010) reported high sensitivity to quinolones, but not to aminoglycoside in subclinical mastitis-causing staphylococci.

No association was observed between phenotypic and molecular tests for biofilm production, corroborating previous studies (Baselga et al. 1993, Arciola et al. 2001, Vasuvedan et al. 2003, Oliveira et al. 2006). Only seven isolates were positive for both methods simultaneously. The Congo Red Agar test is a very simple and inexpensive technique, but correct interpretation of the results depends on many factors, such as colony color characteristics (Baselga et al. 1993). PCR detected more biofilm forming isolates than the Congo red agar test, supporting previous findings (Oliveira et al. 2006). However, the present study focused on the icaD gene alone, while other genetic loci (bap, agr and sar) might be associated with biofilm formation as well (Oliveira et al. 2006). The main occurrence of biofilm in goat isolates is associated with antimicrobial resistance and multidrug resistance, as reported in previous studies (Baselga et al. 1993, Oliveira et al., 2006).

The high antimicrobial resistance rates detected in staphylococci causing mastitis in small ruminants in Northeastern Brazil might be associated with several resistant determinant genes. Considering the lack of information about antimicrobial resistance in staphylococci causing mastitis in small ruminants in Brazil, the present findings could be of great importance in developing strategies for mastitis treatment in the region.

Acknowledgements.- To Pernambuco State Science and Technology Support Foundation (FACEPE) for financial support (post graduate fellowship and First Project Program-PPP/FACEPE No. APQ-0629-5.05/08). To Sisal Regional Development Institute for project financial support and use of facilities.

\section{REFERENCES}

Aires-de-Sousa M., Parente C.E.S.R., Vieira-da-Mota O., Bonna I.C.F., Silva D.A. \& Lencatre H. 2007. Characterization of Staphylococcus aureus isolates from buffalo, bovine, ovine and caprine milk samples collected in Rio de Janeiro, Brazil. Appl. Environ. Microbiol. 73:3845-3849.

Arciola C.R., Baldassarri L. \& Montanaro L. 2001. Presence of icaD genes and slime production in a collection of Staphylococcal strains from catheterassociated infections. J. Clin. Microbiol. 39:2151-2156.

Baselga R., Albizu I., De La Cruz M., Del Cacho E., Barberan M. \& Amorena B. 1993. Phase variation of slime production in Staphylococcus aureus: Implications in colonization and virulence. Infect. Immun. 61:4857-4862.

Bergonier D., De Crémoux R., Rupp R., Lagriffoul G. \& Berthelot X. 2003. Mastitis of dairy small ruminants. Vet. Res. 34:689-716.

Bjorland J., Steinum T., Kvitle B., Waage S., Sunde M. \& Heir E. 2005. Widespread distribution of disinfectant resistance genes among staphylococci of bovine and caprine origin in Norway. J. Clin. Microbiol. 43:4363-4368.

Butaye P., Cloeckaert A. \& Schwarz S. 2003. Mobile genes coding for efflux-mediated antimicrobial resistance in gram-positive and gram-negative bacteria. Int. J. Antimicrob. Agents 22:205-210.

CLSI 2006. Methods for dilution antimicrobial susceptibility tests for bacteria that grow aerobically: Approved standards. Clinical and Laboratory Standards Institute, Document CLSI M7-A7, CLSI, Wayne, Pennsylvania.
Contreras A., Sierra D., Sánchez A., Corrales J.C., Marco J.C., Paape M.J. \& Gonzalo C. 2007. Mastitis in small ruminants. Small Rumin. Res. 68:145153.

Fiebelkorn K.R., Crawford S.A., McElmeel M.L. \& Jorgensen J.H. 2003. Practical disk diffusion method for detection of inducible clindamycin resistance in Staphylococcus aureus and coagulase-negative staphylococci. J. Clin. Microbiol. 41:4740-4744.

Gatermann S.G., koschinski T. \& Friedrich S. 2007. Distribution and expression of macrolide resistance genes in coagulase-negative staphylococci. Clin. Microbiol. Infect. 13:777-781.

Greco C., Mastronardi C., Pagotto F., Mack D. \& Ramirez-Arcos S. 2008. Assessment of biofilm-forming ability of coagulase-negative staphylococci isolated from contaminated platelet preparations in Canada. Transfusion 48:969-977.

Guérin-Faublée V., Carret G. \& Houffstchmitt P. 2003. In vitro activity of 10 antimicrobials agents against bacteria isolated from cows with clinical mastitis. Vet. Rec. 152:466-471.

Hassan K.A., Skurray R.A. \& Brown M.H. 2007. Active export proteins mediating drug resistance in Staphylococci. J. Mol. Microbiol. Biotechnol. 12:180-196.

Hussain A., Shakoor A., Shahid M.A., Numam M. \& Gulraiz F. 2007. Clinical and subclinical Staphylococcus aureus mastitis in dairy buffaloes: Disease characteristics and antibiotic susceptibility profiles of isolates. Int. J. Agric. Res. 2:804-811.

Katayama Y., Robinson D.A., Enright M.C. \& Chambers H. 2005. Genetic background affects stability of mecA in Staphylococcus aureus. J. Clin. Microbiol. 43:2380-2383.

Krumperman P.H. 1983. Multiple antibiotic resistance indexing of Escherichia coli to identify high-risk sources of fecal contamination of foods. Appl. Environ. Microbiol. 46:165-170.

Kwon N.H., Park K.T., Moon J.S., Jung W.K., Kim S.H., Kim J.M., Hong S.K., Koo H.C., Joo Y.S. \& Park Y.H. 2005. Staphylococcal cassette chromosome mec (SCCmec) characterization and molecular analysis for methicillin-resistant Staphylococcus aureus and novel SCCmec subtype IVg isolated from bovine milk in Korea. J. Antimicrob. Chemother. 56:624-632.

Kumar R., Yadav B.R. \& Singh R.S. 2009. Genetic determinants of antibiotic resistance in Staphylococcus aureus isolates from milk of mastitic crossbred cattle. Curr. Microbiol. 60:379-386.

Murakami K.W., Minamide W., Wada K., Nakamura E., Teraoka H. \& Watanabe S. 1991. Identification of methicillin resistant strains of staphylococci by polymerase chain reaction. J. Clin. Microbiol. 29: 2240-2244.

Oliveira M., Bexiga R., Nunes S.F., Carneiro C., Cavaco L.M., Bernardo F. \& Vilela C.L. 2006. Biofilm-forming ability profiling of Staphylococcus aureus and Staphylococcus epidermidis mastitis isolates. Vet. Microbiol. 118:133-140.

Olsen J.E., Christensen H. \& Aarestrup F.M. 2006. Diversity and evolution of blaZ from Staphylococcus aureus and coagulase-negative staphylococci. J. Antimicro. Chemother. 57:450-460.

Onni T., Sanna G., Larsen J. \& Tola S. 2010. Antimicrobial susceptibilities and population structure of Staphylococcus epidermidis associated with ovine mastitis. Vet. Microbiol. 148:45-50.

Pitkälä A., Haveri M., Pyölärä S., Myllys V. \& Honkanen-Buzalski T. 2004. Bovine mastitis in Finland 2001: Prevalence, distribution of bacteria, and antimicrobial resistance. J. Dairy. Sci. 87:2433-2441.

Phillips I., Casewell M., Cox T., Groot B.D., Friis C., Jones R., Nightingale C., Preston R. \& Waddell J. 2004. Does the use of antibiotics in food animals pose a risk to human health? A critical review of published data. J. Antimicrob. Chemother. 53:28-52.

Pyörälä S. \& Taponen S. 2009. Coagulase-negative staphylococci\; emerging mastitis pathogens. Vet. Microbiol. 134:3-8.

Quinn P.J., Carter M.E., Markey B. \& Carter G.R. 1994. Clinical Veterinary Microbiology. Wolfe, London. 648p.

Rabello R.F., Souza C.R., Duarte R.S., Lopes R.M., Teixeira L.M. \& Castro A.C. 2005. Characterization of Staphylococcus aureus isolates recovered from bovine mastitis in Rio de Janeiro, Brazil. J. Dairy Sci. 88:3211-3219. 
Ribeiro M.G., Geraldo J.S., Langoni H., Lara G.H.B., Siqueira A.K., Salerno T. \& Fernandes M.C. 2009. Microrganismos patogênicos, celularidade e resíduos de antimicrobianos no leite produzido no sistema orgânico. Pesq. Vet. Bras. 29:52-58.

Sawant A.A., Gillespie B.E. \& Oliver S.P. 2009. Antimicrobial susceptibility of coagulase-negative Staphylococcus species isolated from bovine milk. Vet. Microbiol. 134:73-81.

Schmidt V., Pinto A.T., Schneider R.N., Silva F.F.P. \& Mello F.A. 2009. Caracterização da mastite subclínica em caprinos produzidos em sistema orgânico no Rio Grande do Sul. Pesq. Vet. Bras. 29:774-778.

Silva E.R., Siqueira A.P., Martins J.C.D., Ferreira W.P.B. \& Silva N. 2004. Identification and in vitro antimicrobial susceptibility of Staphylococcus species isolated from goat mastitis in the Northeast of Brazil. Small Rumin. Res 55:45-49.

Soares L.C., Pereira I.A., Coelho S.M.O., Cunha C.M.M., Oliveira D.F.B., Miranda A.N. \& Souza M.M.S. 2008. Caracterização fenotípica da resistência a antimicrobianos e detecção do gene mecA em Staphylococcus spp. coagulase - negativos isolados de amostras animais e humanas. Ciênc Rural 38:1346-1350.

Taponen S. \& Pyörälä S. 2009. Coagulase-negative staphylococci as cause of bovine mastitis-Not so different from Staphylococcus aureus? Vet. Microbiol. 134:29-36.

Vasuvedan P., Nair M.K.M., Annamalai T. \& Venkitanarayanan K.S. 2003. Phenotypic and genotypic characterization of bovine mastitis isolates of Staphylococcus aureus for biofilm formation. Vet. Microbiol. 92:179-185.

Vesterholm-Nielsen M., Larsen M.O., Olsen J.E. \& Aarestrup F.M. 1999. Occurrence of the blaZ gene in penicillin resistant Staphylococcus aureus isolated from bovine mastitis in Denmark. Acta Vet. Scand. 40:279-86.

Virdis S., Scarano C., Cossu F., Spanu V., Spanu C. \& Santis E.P.L. 2010. Antibiotic resistance in Staphylococcus aureus and coagulase negative staphylococci isolated from goats with subclinical mastitis. Vet. Med. Int. 2010:517060, doi: 10.4061/2010/517060. 